\title{
Good IT Governance: Framework and Prototype for Higher Education
}

\author{
Henderi ${ }^{1}$ \\ e-mail: henderi@pribadiraharja.com
}

Diterima: 4 Desember 2009/Disetujui: 18 Desember 2009

\begin{abstract}
Information technology (IT) is becoming increasingly important for higher education (and others) that can facilitate the implementation of business processes and enhance competitive advantage. Through IT, business processes can be implemented more easily, quickly, efficiently, and effectively. IT also offers many opportunities for universities to improve performance, transforming the service, market, work processes, and community relations and researches. Therefore, the current IT governance to be one critical success factor (CSF) for leaders (CIOs) and partner universities to optimize the role of IT in improving asset effectiveness, performance achievements, goals, objectives, mission, and vision of the organization. However, the complexity of the application of IT in the organization caused difficulties at various levels of leaders and stakeholders in understanding, creating and implementing IT governance in higher education. As a result the benefits of using IT to get higher education is felt not worth the investment value that has been issued. Therefore, this article discusses an overview of IT governance principles and guidelines established by experts in the field IT governance, IT governance structures in higher education, IT governance committees intensively, and recommendations for good IT governance prototype that can be applied in higher education.
\end{abstract}

Keywords: Good IT governance, Critical success factor (CSF), prototype, university

\section{ABSTRAKSI}

Information technology (IT) menjadi semakin penting bagi organisasi perguruan tinggi (dan organisasi lainnya) karena dapat memudahkan pelaksanaan proses bisnis dan meningkatkan keunggulan kompetitif. Melalui IT, proses bisnis dapat dilaksanakan lebih mudah, cepat, efisien, dan efektif. IT juga menawarkan banyak peluang kepada perguruan tinggi untuk meningkatkan kinerja, mentransformasi pelayanan, pasar, proses

1. Dosen Jurusan Teknik Informatika, STMIK Raharja

Jl. Jend Sudirman No.40 Modern Cikokol-Tangerang Telp 5529692 
kerja, dan hubungan-hubungan komunitas dan riset. Karenanya, IT governance saat ini menjadi salah satu critical success factor (CSF) bagi para pemimpin (ClOs) dan mitra perguruan tinggi untuk mengoptimalkan peran IT dalam efektifitas peningkatan aset, capaian kinerja, sasaran, tujuan, misi dan visi organisasi. Namun demikian, kompleksitas penerapan IT pada organisasi menimbulkan kesukaran pada berbagai level pemimpin dan stakeholder dalam memahami, membuat dan menerapkan IT governance di perguruan tinggi. Akibatnya manfaat penggunaan IT yang didapatkan perguruan tinggi dirasakan belum sebanding dengan nilai investasi yang telah dikeluarkan. Untuk itu, artikel ini membahas tinjauan tentang IT governance, prinsipprinsip dan pedoman yang ditetapkan oleh para ahli IT governance di lapangan, struktur IT governance di perguruan tinggi, komite IT governance secara intensif, dan rekomendasi prototype good IT governance yang dapat diterapkan di perguruan tinggi.

Kata Kunci: Good IT governance, Critical success factor (CSF), prototype, perguruan tinggi

\section{PENDAHULUAN}

Pemanfaatan information technology (IT) oleh banyak perusahaan dalam melaksanakan business process-nya telah menginspirasi para pemimpin perguruan tinggi menerapkan IT untuk meningkatkan kemampuan kompetitif dan mentransformasi pelayanan, proses kerja, dan hubungan antar komunitas civitas akademik, peneliti, dan berbagai level kepentingan dan stakeholder. Karena itu penerapan IT perlu disusun secara hati-hati dan bersinergi antara teknologi dan spesialis bisnis perguruan tinggi. Pada banyak kasus, tata cara penerapan IT organisasi dan pengaruhnya, serta penyelenggaraan IT organisasi telah dipadu dengan terencana dan hati-hati melalui penerapan kebijakan tata kelola IT (IT governance). Hal ini dilakukan untuk meningkatkan peran IT dalam capaian kinerja, peningkatan aset organisasi, mentransformasi pelayanan, pasar, proses kerja, hubungan-hubungan bisnis, dan meningkatkan keunggulan kompetitif perguruan tinggi. Sementara itu, keberhasilan beberapa perusahaan dalam meningkatkan capaian tujuan dan sasaran, kemampuan kompetitif, dan keuntungan bisnisnya melalui penerapan I T governance telah banyak menginspirasi para pemimpin perguruan tinggi untuk meningkatkan IT governance institusinya.

Pada sisi yang lain, cukup banyak perguruan tinggi yang telah menerapkan IT menyatakan belum puas dengan kinerja dan peranan IT terhadap peningkatan kinerja, pelayanan dan pencapaian tujuan organisasi. Peranan IT terhadap peningkatan kinerja dirasakan belum cukup signifikan seperti yang diharapkan. Karenanya para pemimpin perguruan tinggi telah membuat berbagai usaha untuk meningkatkan pemahaman tentang bagaimana IT dioperasikan, dan yang lebih penting adalah bagaimana IT dapat 
digunakan untuk mempengaruhi corporate governance, meningkatkan kinerja, mencapai tujuan dan sasaran, dan meningkatkan keunggulan kompetitif organisasi.

\section{Ruang Lingkup}

Sebagian besar perguruan tinggi menggunakan IT bertujuan untuk mendukung kegiatan back office, front office, dan berbagai aktivias organisasi lainnya. Walau demikian, cukup banyak perguruan tinggi (terutama di Indonesia) yang belum memperhatikan dan menerapkan prinsip, framework dan cara kerja good IT governance dengan baik. Akibatnya manfaat penggunaan IT yang didapatkan dirasakan belum sebanding dengan nilai investasi yang telah dikeluarkan. Hal ini sejalan dengan laporan Meta Group yang menyatakan bahwa lebih dari $80 \%$ dari 2000 organisasi global tidak mempunyai komite governance. Sementara analis perusahaan juga memperkirakan bahwa $50 \%$ dari perusahaan akan berusaha untuk meningkatkan kebijakan IT governance-nya [1]. Sementara dari aspek kinerja organisasi, penerapan IT governance yang baik dan efektif juga dapat meningkatkan capaian kinerja hingga mencapai $20 \%$ [2]. Untuk itu, artikel ini membahas tentang tinjauan IT governance, prinsip-prinsip dan pedoman yang ditetapkan oleh para ahli IT governance, struktur IT governance di perguruan tinggi, komite IT governance secara intensif, dan rekomendasi prototype good IT governance di perguruan tinggi untuk meningkatkan capaian kinerjanya melalui penerapan prinsip dan cara kerja good IT governance.

\section{PEMBAHASAN}

\section{Overview Definisi IT Governance}

Definisi mengenai IT governance telah dimuat dan dijelaskan pada banyak literatur. Beberapa diantaranya menyatakan bahwa IT governance merupakan sebutan lain dari ICT governance. Sementara itu, Peter Weil dan J eanne Ross mendefinisikan IT governance sebagai 'wewenang dan tanggungjawab dalam menetapkan keputusan kerangka kerja IT untuk mendorong perilaku yang baik dalam penggunaan IT' [3]. Pada bagian ini, Weill dan Ross membimbing definisi dan prinsip-prinsip untuk mengembangkan dan menerapkan hak menetapkan keputusan dalam framework IT. Definisi dan prinsip ini sejalan dengan yang disampaikan oleh henderi et. all bahwa IT governance adalah wewenang dalam menetapan keputusan landasan kerja secara benar dan bisa dipertanggungjawabkan untuk mendorong keinginan, kebiasaan, dan pengukuran kinerja penggunaan IT dengan mempertimbangkan maksud, tujuan, dan sasaran bisnis perusahaan [4]. Dengan demikian definisi dan tujuan IT governance dapat digambarkan dalam bentuk diagram berikut. 


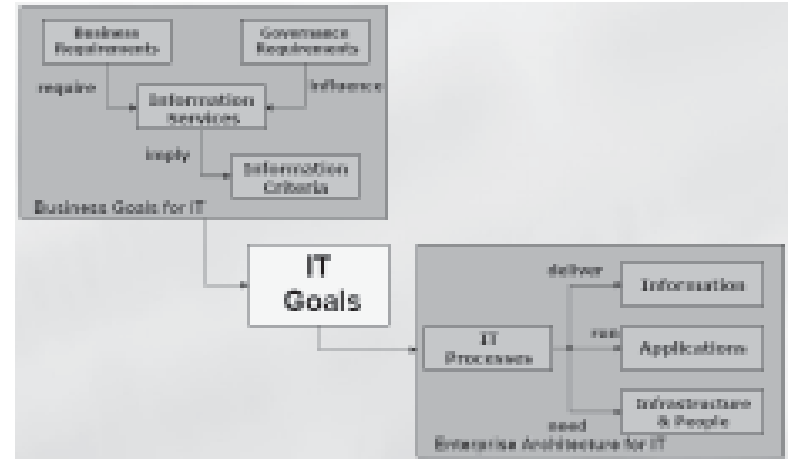

Gambar 1. Pendekatan Definisi dan Tujuan Implementasi IT Governance [5]

\section{Prinsip IT Governance}

IT governance institute dan beberapa institusi riset dan profesional IT telah membuat dan mengeluarkan beberapa prinsip dasar IT governance. Salah satu prinsip yang cukup komprehensif adalah yang dikembangkan dan disusun oleh Weill dan Ross. Prinsip ini dibangun berdasarkan field reseaches pada ratusan organisasi dan perusahaan. Berikut adalah sepuluh prinsip IT governance yang disusun secara ringkas dan ditujukan untuk memberikan gambaran kepada para pemimpin sebagai referensi dalam melakukan perbaikan IT governance organisasi [6]:

\section{(a) Desain aktif governance}

Patching terhadap masalah yang timbul merupakan taktik defensif untuk membatasi peluang dampak strategis penerapan IT. Karenanya, manajemen harus aktif merancang IT governance organisasi untuk mencapai tujuan dan sasaran kinerja. Merancang IT governance secara aktif harus melibatkan para eksekutif senior yang memimpin dan mengalokasikan sumber daya, perhatian, dan dukungan terhadap proses.

\section{(b) Mengetahui Kapan Harus Mendesain Ulang}

Meninjau kembali seluruh struktur governance. Mengharuskan semua individu mempelajari peran dan struktur hubungan yang baru. Hal ini membutuhkan waktu. Dengan demikian, ClOs jarang melakukan desain ulang. Namun jika dibutuhkan perubahan dalam governance perlu dilakukan dengan tujuan melakukan perubahan perilaku sesuai dengan yang diinginkan.

\section{(c) Melibatkan Para Manajer Senior}

Agar implementasi IT governance sukses maka $\mathrm{ClOs}$ harus terlibat secara efektif. Manajer senior lainnya juga harus berpartisipasi dalam komite, proses persetujuan, dan penilaian kinerja. 


\section{(d) Membuat Pilihan.}

Governance yang baik, seperti halnya corporate stategy membutuhkan pilihan. Demikian pula IT governance tidak mungkin diciptakan untuk dapat memenuhi setiap tujuan, tetapi governance dapat dan harus menyoroti tujuan yang saling bertentangan dan mencari titik temunya. Seiring dengan peningkatan perkembangan organiasi, governance akan menjadi lebih kompleks. Organisasi dengan performa terbaik harus mampu menangani konflik dengan prinsipprinsip bisnis yang jelas. Prinsip IT governance yang dihasilkan juga harus mencerminkan prinsip-prinsip bisnis ini.

\section{(e) Memperjelas Proses Penanganan Pengecualian}

Dalam IT, pengecualian artinya menantang status quo, khususnya arsitektur IT dan infrastruktur. Beberapa permintaan bersifat pengecualian, dan tidak sesuai prosedur. Namun sebagian besar berasal dari hasrat yang tinggi untuk memenuhi kebutuhan bisnis. J ika pengecualian yang diusulkan oleh sebuah unit bisnis memiliki nilai, dan perubahan ke arsitektur IT bisa bermanfaat bagi seluruh perusahaan maka keperluan seperti ini perlu dibuat prosedur proses penanganan pengecualiannya.

\section{(f) Memberikan I nsentif yang Tepat}

IT governance kurang efektif bila insentif dan sistem penghargaan yang diberikan tidak selaras dengan tujuan organisasi. Governance dan isu kesejajaran insentif adalah isu utama untuk menciptakan sinergi antar unit bisnis. IT governance dirancang untuk mendorong sinergi unit bisnis, otonomi, atau beberapa kombinasi, insentif dari eksekutif juga harus selaras. Jika IT governance telah dirancang dengan baik, namun tidak seefektif seperti yang diharapkan, salah satu penyebabnya adalah insentif yang tidak tepat.

\section{(g) Tetapkan Kepemilikan dan Akuntabilitas untuk IT Governance}

Seperti inisiatif organisasi besar, IT governance harus memiliki ownership dan penanggungjawab. Dewan Direktur atau CEO harus memegang $\mathrm{ClO}$ dan bertanggung jawab atas kinerja IT governance dengan beberapa sistem pengukuran keberhasilan yang jelas.

\section{(h) Desain Governance Pada Berbagai Tingkat Organisasi}

Pada organisasi yang besar, yang memiliki multi unit usaha, organisasi perlu mempertimbangkan IT pada berbagai tingkat governance. Titik awalnya adalah besar-kecilnya organisasi, sehingga IT governance didorong oleh sejumlah strategi dan tujuan perusahaan secara luas. Organisasi dengan fungsi IT 
terpisah di divisi, unit bisnis, atau geografis tetapi tetap dapat terhubung dengan lapisan IT governance.

\section{(i) Menyediakan Transparansi dan Pendidikan}

Organisasi yang lebih transparansi dalam proses governance, akan semakin percaya diri dalam governance.

\section{(j) Melaksanakan Mekanisme Umum Pada Enam Kunci Aset IT Governance}

Komite eksekutif yang ada pada semua issue organisasi, termasuk tentang IT harus menciptakan sinergi dengan mempertimbangkan beberapa asset, yaitu : (1) sumber daya, (2) manusia, (3) keuangan, (4) fisik, (5) intelektual property, (6) informasi dan infrastruktur informasi, dan (7) keterhubungan.

\section{Framework IT Governance}

Weill dan Ross membagi IT governance kedalam tiga unsur yang berbeda yaitu: Domain Keputusan IT, IT Governance Archetypes, dan Mekanisme Implementasi [7]. Namun pada bagian ini akan dijelaskan framework IT governance yang sangat berhubungan dengan domain keputusan IT yang terdiri dari lima domain, yaitu:

1. Prinsip-prinsip IT. Keputusan tingkat tinggi mengenai peran strategis IT dalam bisnis.

2. Arsitektur IT. Terpadu, menetapkan pilihan teknis untuk menuntun organisasi dalam memenuhi kebutuhan bisnis.

3. Infrastruktur IT. Pusat terkoordinasi, layanan IT bersama-sama memberikan dasar bagi kemampuan IT perusahaan, dan biasanya dibuat sebelum kebutuhan penggunaan yang tepat diketahui.

4. Aplikasi kebutuhan bisnis. Persyaratan bisnis untuk membeli atau mengembangkan sendiri secara internal aplikasi IT yang dibutuhkan.

5. Prioritas dan investasi. Keputusan tentang berapa banyak dan di mana investasi dalam bidang IT dilakukan, termasuk persetujuan proyek dan pembenaran teknik.

Berdasarkan penjelasan di atas, maka framework IT governance policy, dan proses pengambilan keputusan tingkat tinggi mengenai peran strategis IT dalam organisasi dapat digambarkan sebagai berikut. 


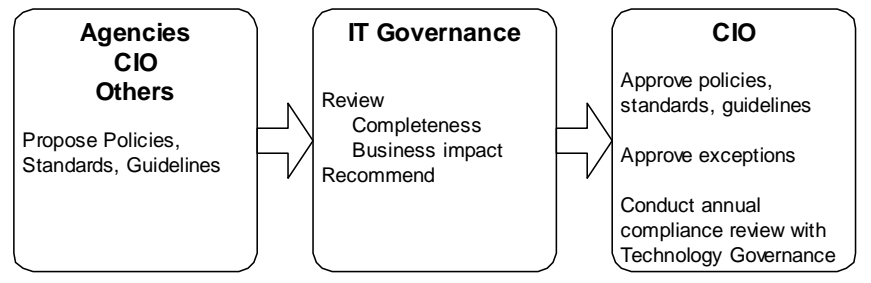

Gambar 2. Framework IT Governance Policy

\section{Prototype IT Governance dan Mekanisme I mplementasi \\ a. Prototype IT Governance}

Weill dan Ross membagi prototype IT governance menjadi enam tipe. Deskripsi keenam pola dasar prototype tersebut adalah sebagai berikut [8]:

1. Bisnis Monarki. Seorang pejabat senior eksekutif bisnis atau sekelompok eksekutif senior, kadang-kadang termasuk $\mathrm{ClO}$.

2. IT Monarki. Individu atau kelompok eksekutif IT.

3. Federal. C-level bisnis eksekutif dan wakil-wakil dari semua kelompok operasitermasuk keterlibatan IT (setara dengan governance pusat, dan bagianbagian bekerja bersama-sama).

4. IT duopoli. Dua pengambilan keputusan yang melibatkan pihak eksekutif IT, dan satu kelompok dari para pemimpin bisnis.

5. Feodal. Proses pengambilan keputusan yang terpisah antara unit bisnis atau pemimpin berdasarkan kebutuhan entitas mereka.

6. Anarki. Tiap individu atau kelompok kecil.

\section{b. Mekanisme I mplementasi}

Mekanisme implementasi prototype IT Governance di atas adalah:

1. Struktur Pengambilan Keputusan. Struktur IT yang paling terlihat adalah mekanisme tata kelola organisasi, peran dan tanggung jawab komite dalam pengambilan keputusan sesuai dengan struktur prototype. Prototype yang berbeda mencerminkan struktur pengambilan keputusan yang berbeda pula.

2. Proses Alignment. Governance yang efektif sebagian besar berhubungan dengan tindakan pengambilan keputusan. Proses manajemen alignment teknik IT untuk mengamankan besarnya keterlibatan manajemen dalam penggunaan IT yang efektif. Proses alignment harus membawa semua orang 
di forum untuk memberikan masukan dengan baik kepada governance, memformalkan keputusan dan menerapkan proses, dan mengimplementasikannya dalam keputusan. Kunci sukses proses alignment meliputi proses usulan investasi IT, arsitektur proses pengecualian, perjanjian tingkat layanan, chargeback, proyek pelacakan dan pelacakan formal nilai bisnis IT.

3. Komunikasi formal. Mekanisme komunikasi dimaksudkan untuk mensosialisasikan keputusan IT dan proses-proses governance dan perilaku terkait yang diinginkan dalam organisasi. Hal ini karena hambatan terbesar pada IT governance yang efektif adalah kurangnya pemahaman tentang bagaimana keputusan dibuat atau tentang proses penggunaan IT secara efektif dalam perusahaan. Untuk itu, mekanisme komunikasi manajemen governance dapat dilakukan dalam berbagai cara: pengumuman manajemen senior, komite formal, kantor $\mathrm{ClO}$, kantor IT governance, komunikasi satu persatu, dan berbasis portal web. Seperti proses alignment yang lainnya, mekanisme IT governance perlu dikomunikasikan secara formal agar governance yang terkait lebih efektif .

\section{Protoype IT Governance Pada Organisasi Perguruan Tinggi}

Hasil penelitian terhadap penerapan IT governance pada beberapa perguruan tinggi terbaik di dunia menyimpulkan bahwa sebagian besar perguruan tinggi tersebut telah menerapkan prinsip good IT governance. Berikut ringkasan hasil penelitian yang tersebut.

\section{a. Massachusetts I nstitute of Technology (MI T)}

IT governance di Massachusetts I nstitute of Technology (MIT) dirancang dan diterapkan sesuai dengan kebutuhan MIT. Departemen IT di MIT disebut Informations Services \& Technology ( IS \& T), dan mempunyai struktur organisasi sebagai berikut. 


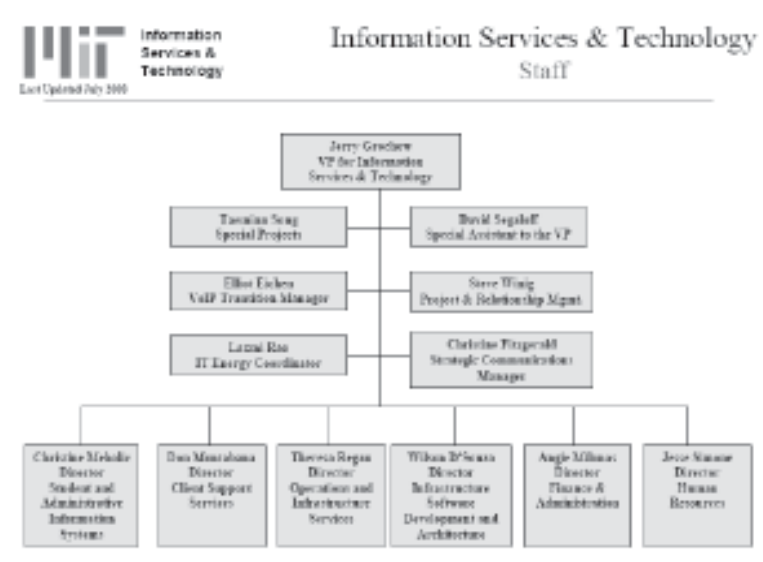

Gambar 3. Struktur Organisasi Departemen IT pada MIT [9]

IS \& T di MIT dipimpin oleh Vice President. Di bawah Vice President IS \& T dibagi menjadi lima departemen. Deskripsi kelima departemen tersebut adalah sebagai berikut [10].

1. Client Support Services: Client Support Services terdiri dari departemen dukungan teknis, kontak awal dan penyelesaian masalah melalui bantuan layanan, pelatihan, komunikasi dan bantuan konsultasi kepada masyarakat, produk-produk perangkat lunak, dan kesiapan keamanan dan respon kepada klien.

2. Infrastructure Software Development and Architecture: menciptakan, mempertahankan, dan mempromosikan infrastruktur perangkat lunak yang fleksibel dengan arsitektur komponen dan antarmuka yang mudah digunakan (dan dipakai) oleh pengembang perangkat lunak di MIT.

3. Operations and I nfrastructure Services: memberikan layanan dasar IT kepada masyarakat seperti jaringan dan aplikasi berbasis jaringan, operasi jasa dan agregasi data, dan administrasi pendukung berbagai kegiatan akademis, penelitian dan administratif.

4. Student Administrative I nformation Systems (SAI S): untuk menjembatani teknologi bisnis dan keahlian dalam berbagai bidang fungsional, termasuk keuangan, logistik, dan sumber daya manusia. 
SAIS juga menyediakan layanan teknologi bisnis yang andal dan responsif untuk MIT.

5. Telephony IS \& T Humas Resouces and Administatve Service: a.Memberikan layanan pengadaan telepon yang kuat, handal dan hemat biaya (suara, voice mail, panggilan konferensi, dan lainnya) kepada komunitas MIT.

b.IS \& I Sumber Daya Manusia dan Jasa Administrasi Jasa: menyediakan sistem keuangan yang berkualitas, pelayanan situs dan sumber daya manusia kepada staf IS \& T, khususnya Tim Kepemimpinan IS \& T. J asa keuangan meliputi persiapan ramalan triwulanan, pemantauan dan mengkonsulidasi pengeluaran.

Selain itu, MIT juga menciptakan tujuh tema strategis untuk membantu memfokuskan operasi IS \& T. Tema-tema tersebut adalah [11]:

1. Services Orientation: memahami pekerjaan dan tujuan staf dan organisasi di MIT untuk meningkatkan fokus MIT pada penyediaan pelayanan kelas dunia sebagai mitra sejati klien;

2. Technological I nnovation and Leadership: menghasilkan ide dan eksperimen yang mengarah kegenerasi layanan IT berikutnya;

3. Collaboration: bekerja sama dengan departemen IT lainnya di kampus dan pengguna IT di seluruh MIT dan rekan di kampus lain, untuk mendorong lingkungan kolaboratif untuk pemecahan masalah, merencanakan kebutuhan IT dimasa depan, dan untuk memastikan dukungan layanan informasi dan teknologi yang tersedia di MIT semakin menjadi yang terbaik dan paling efektif;

4. Communication: meningkatkan arus informasi ke seluruh IS \& T dan komunitas MIT, melibatkan klien dan rekan melalui sebuah dialog tentang kebutuhan dan prioritas IT, meningkatkan visibilitas dan manfaat dari layanan IT, menciptakan identitas IS \& T sebagai organisasi pelayanan yang efektif;

5. Exellence in Project Executioan and Management: adanya penjadwalan sistem anggaran pengiriman hardware dan software yang memenuhi atau melebihi harapan klien;

6. A hight degree of fiscal responsibility coupled with sound financial management (tanggung jawab fiskal tingkat tinggi yang digabungkan dengan manajemen keuangan yang sehat); 
7. Personnel Development: memberikan kesempatan kepada setiap anggota komunitas IS \& T untuk memberikan kontribusi terbaik sesuai kemampuan.

\section{b. Harvard University}

Organisasi IT di Harvard University sangat desentralisasi. Unit pusat IT dikenal sebagai Central Administrasi IT (Cait) yang dipimpin oleh Senior Associate Provost Universitas dan $\mathrm{ClO}$. Tujuan utama organisasi Cait adalah implementasi yang konsisten dan best practice dalam manajemen IT yang efektif untuk memenuhi kebutuhan Universitas secara luas serta kebutuhan yang beragam dari unit administratif utama di pusat governance. Cait dibagi menjadi tiga unit utama, yaitu [12]:

1.Unit Teknologi Akademik, disebut iCommons, menyediakan seperangkat sumber daya online untuk proses belajar mengajar, sumber daya dapat berkembang dan dikelola secara lokal dengan kustomisasi, konten yang unik dari klien, dan untuk setiap sekolah. Unit ini juga memberikan dukungan, pelatihan, layanan konsultasi, dan dokumentasi untuk klien Harvard dan pengguna.

2. Teknologi Administratif unit, dikenal sebagai The Office for Administratif Systems (OAS), bermitra dengan Kantor Administrasi Keuangan dan Sumber Daya Manusia Harvard dalam menyediakan proses teknis dan keahlian dalam pengembangan dan dukungan dari sistem governance pusat.

3.I nfrastruktur Teknologi unit, dikenal sebagai University Informaton Systems (UIS), menyediakan sesuatu yang diandalkan dan infrastruktur teknologi yang kuat, mencakup dukungan untuk jaringan data Harvard, membina hubungan dengan pemasok teknologi strategis dan memberikan layanan IT yang efektif untuk Universitas.

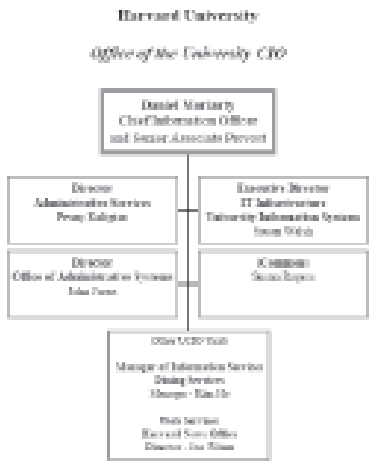

Gambar 4. Struktur IT Governance di Harvard University [12] 
Selain mengelola IT melalui unit-unit tersebut dan tampak pada gambar struktur di atas, Dinas $\mathrm{ClO}$ di Harvard melibatkan kolaborasi dari Sekolah Harvard yang diseleksi vendor, pengaturan standar teknologi desktop, jaringan perangkat tambahan, pengembangan web, dan dukungan teknologi akademis [13]. Hal ini dilakukan melalui ClO Advisory Group, yang terbagi menjadi tiga subkelompok: (1) Customer Advisory Groups, (2) Komite Pengarah, dan (3) Briefings. Berikut adalah deskripsi untuk tiap subkelompok tersebut [13]:

1.Customer Advisory Groups, sebuah panel yang terdiri dari klien dan stakeholder yang berkumpul secara teratur untuk meninjau dan membahas keuangan teknologi baru, program, dan jasa. Kelompok in bertanggung jawab untuk memberikan masukan yang signifikan dan rekomendasi untuk membantu menetapkan keseluruhan arah dan mempengaruhi pengambilan keputusan.

a.Network Operations Advisory Group; membawa perspektif Network Operations Center Universitas menilai pengaturan layanan produk dan model, dan memandu penerapan standar teknologi NOC dan arsitektur yang dibutuhkan oleh Universitas.

b.Server Operation Advisory Group: membawa perspektif Server Operations Center Universitas menilai pengaturan dan layanan produk dan model, dan untuk memandu penerapan standar teknologi SOC dan arsitektur yang dibutuhkan oleh Universitas.

c. Telecom Advisory Group: membawa perspektif Telecom Universitas untuk menilai pengaturan dan model produk dan jasa; mengelola kinerja keuangan sesuai peraturan dan kebijakan pusat layanan.

d.Web Advisory Group: mengidentifikasi kebutuhan dan fungsional bisnis secara umum yang dapat diatasi dengan teknologi web dan merekomendasikan keuangan, bisnis dan strategi operasi (website development services) untuk memenuhi kebutuhan pelanggan.

e.iCommons Steering Committee: memandu pengembangan berkelanjutan dari iCommons toolset akademik dan menginformasikan kegiatan dukungan ke sekolah-sekolah.

f.Apple Advisory Council: mengelola hubungan antara Harvard dengan vendor pengadaan desktop, mengkomunikasikan pembaruan dan perubahan kepada masyarakat, dan mendapatkan masukan dari pelanggan Harvard mengenai persyaratan desktop. 
g. Tech Services Product Roadmap Group - Levono: mengatur hubungan antara Harvard dengan Lenovo untuk pengadaan PC/Desktop, mengkomunikasikan pembaruan dan perubahan kepada masyarakat dan mendapatkan masukan dari pelanggan Harvard tentang persyaratan pengadaan pada PC/desktop.

h. Cl O Standing Committee: membantu perkembangan komunikasi, merangsang dialog tentang teknologi, dan mengeksplorasi kesempatan kerjasama dengan $\mathrm{ClO}$ di Universitas.

2.Steering Commitees: kelompok pemangku kepentingan yang bertanggung jawab untuk memberikan arahan pada arah strategis secara keseluruhan. Steering Commitees bertanggung jawab terhadap keputusan-keputusan kebijakan.

a.Directory Executive Committee: mengembangkan, meninjau, dan mengevaluasi data direktori kebijakan teknis, standar, arsitektur, peraturan dan isu kepatuhan.

b. University Technology Architecture Group: mengembangkan, meninjau dan mengevaluasi kebijakan teknis IT Universitas, standar, arsitektur, perundang-undangan, dan isu-isu kepatuhan; menyusun pedoman untuk pelaksanaan sesuai dengan keperluan.

3.Briefing: kelompok ini secara langsung dan tidak langsung berkumpul secara teratur untuk menerima sebuah komentar inisiatif yang ada atau sesuai dengan yang diharapkan.

a.IT Forum: berbagi ide-ide dan praktek; membahas isu-isu terbaru; mengusulkan dan melakukan inisiatif updating terhadap teknologi utama.

\section{c. Universitas British Columbia}

IT di University of British Columbia (UBC) menyediakan strategi yang berkaitan dengan IT, aplikasi, infrastruktur, dan dukungan layanan kepada civitas UBC [14]. UBC membentuk sebuah e-strategy framework untuk menyelaraskan inisiatif teknologi dengan sasaran-sasaran strategis universitas. Kerangka ini mendorong kemitraan antara IT dan kelompok-kelompok di kampus, untuk meneliti, merencanakan dan menerapkan teknologi yang memungkinkan civitas akademik berprestasi. Departemen IT menerapkan kepemimpinan dan layanan IT kepada pelanggan yang prima, dan hubungan kolaboratif dengan komunitas riset. Struktur IT governance UBC dipimpin oleh seorang $\mathrm{ClO}$ dan Associate Vice President bidang IT. Di bawah Cl O, ada Administrator dan Direktur Eksekutif IT. Direktur Eksekutif mengawasi seluruh operasi enam komponen IT Universitas berikut [15]: 
1.I nfrastruktur: menyediakan layanan infrastruktur IT kampus, seperti jaringan, nirkabel, layanan suara, layanan hosting, dan pengelolaan jaringan.

2. Keuangan: bertanggung jawab untuk pengolahan piutang dan pembayaran, dan kinerja keuangan Departemen IT.

3. Aplikasi: bertanggung jawab untuk menyampaikan sejumlah aplikasi UBC's enterprise seperti email, identitas manajemen, dan WebCT. Aplikasi juga mendukung dan memberikan aplikasi yang memungkinkan IT melakukan operasi internal.

4. Strategi: memastikan strategi IT dan mengantisipasi kebutuhan IT kampus secara luas; membangun hubungan dengan para stakeholder kunci di fakultas dan unit-unit administratif, dan memberikan dukungan kepemimpinan untuk menjaga standar tinggi keamanan IT di UBC. Untuk memenuhi tujuan tersebut, strategi IT aktif dalam tiga bidang utama: strategi, kemitraan dan keamanan IT.

5. Dukungan: bertanggung jawab untuk bekerja sama dengan masyarakat untuk mengidentifikasi bagian IT UBC mana yang dapat memenuhi teknologi masa depan atau sesuai kebutuhan, menyampaikan informasi kepada masyarakat IT UBC melalui web, dan menyediakan dukungan IT kepada yang mempunyai banyak produk dan layanan. Kelompok ini juga bertanggung jawab untuk melakukan komunikasi internal dan eksternal dalam departemen IT, dan membantu koordinasi dalam beragam acara kampus.

6. Sumber Daya Manusia dan Administrasi: memberikan dukungan dalam berbagai kegiatan sumber daya manusia, dan memimpin group administrasi. Group administratif memberikan dukungan dalam bidang-bidang yang berkaitan dengan fasilitas dan administrasi.

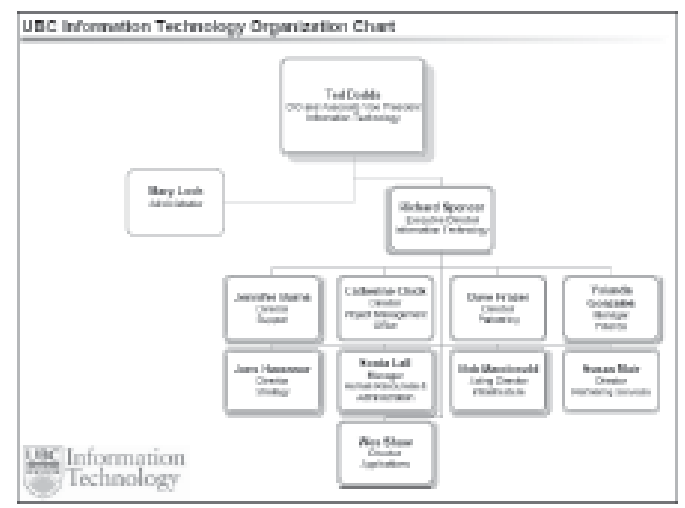

Gambar 5. Struktur IT governance Universitas British Columbia [16] 
Selain menetapkan struktur IT governance, UBC juga mendirikan empat kelompok kerja untuk memandu inisiatif dan operasi IT. UBC menggambarkan group-group ini dan perannya melalui situs Web sebagai berikut [16]:

1. Komite Pengarah Eksekutif: bertanggungjawab dalam hal: (a) menyediakan kepemimpinan dan dorongan terhadap budaya, proses dan perubahan organisasi; (b) menyetujui sasaran-sasaran strategis untuk eStrategy; (c) menyetujui atau merekomendasikan pendanaan proyek-proyek strategis dan inisiatif; (e) aktif mempelopori kampanye e-Srategy, mendorong unit untuk berkolaborasi pada solusi umum dalam kerangka e-Strategy; (f) mempelopori re-interpretasi atau mengubah peraturan/kebijakan jika diperlukan; (g) memastikan upaya e-Strategy difokuskan pada kebutuhan dan manfaat bagi pengguna akhir.

2. Dewan Pertimbangan e-Strategy: secara bersama membawa wakilwakil dari fakultas dan departemen dari seluruh kampus untuk mempromosikan tujuan-tujuan e-Strategy di dalam komunitas universitas, dan memberikan bimbingan dan dukungan yang berkelanjutan untuk inisiatif e-Strategy, termasuk perencanaan dan penetapan prioritas.

3. I dentity Management Advisory Committee (I dMAC): perlunya pendekatan manajemen terpadu untuk mengidentifikasi kebutuhan manajemen secara luas. Campus-Wide login menyediakan mekanisme otentikasi yang digunakan oleh sejumlah besar aplikasi, seperti: pendistribusian peran pengelolaan dan keanggotaan kelompok, pendistribusian akses informasi yang tepat kepada beberapa staf pada seluruh sistem, atau satu mekanisme untuk memungkinkan individu memperbarui informasi pribadi dalam berbagai sistem. Menangani sejumlah inisiatif sistem, baik yang sedang direncanakan atau sedang berlangsung secara bersamasama.

4. Panitia Pengarah Sistem Course Management: mandat komite adalah untuk memastikan sistem manajemen kursus UBC bekerja dengan baik untuk mahasiswa, staf pengajar dan adminstrasi, dengan membuat keputusan universitas secara luas dengan berkonsultasi kepada unit lokal. Panitia dibuat setelah periode konsultasi yang intensif dengan komunitas e-pembelajaran yang terdiri dari berbagai perwakilan dan kepentingan stakeholder, termasuk pengguna akhir dan stakeholder yang memahami teknologi dan persimpangan antara kegiatan belajar - mengajar. 


\section{Rekomendasi Prototype Good I T Governance untuk Perguruan Tinggi}

Berdasarkan hasil penelitian, observasi dan analisis terhadap prinsip dasar, prototype dan implementasi I T governance pada beberapa universitas terbaik di atas, maka prototype IT governance pada perguruan tinggi dapat digambarkan dalam suatu bagan prototype berikut.

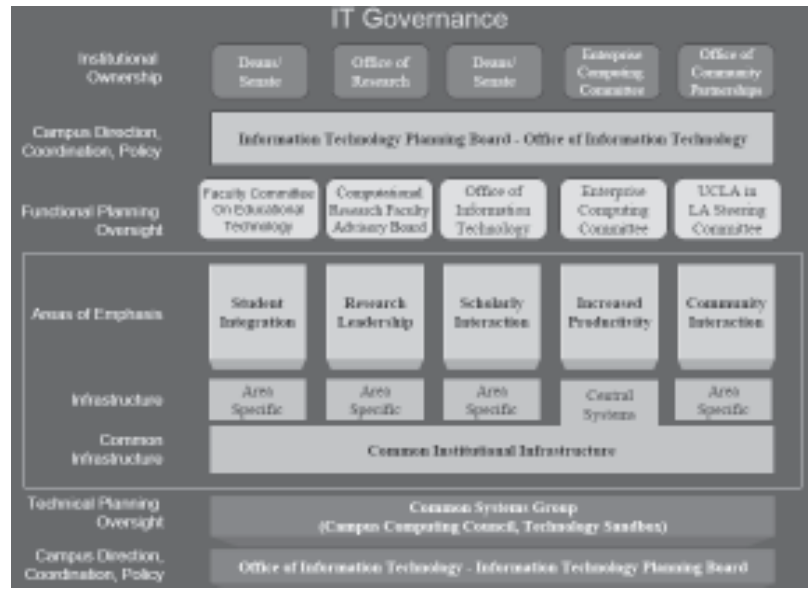

Gambar 6. Rekomendasi Prototype IT Governance untuk Perguruan Tinggi

Tampak pada gambar enam di atas, struktur IT governance pada perguruan tinggi secara umum terdiri dari enam kunci utama, yaitu:

1. Institutional Ownership (Deans/Senate, Office of Reseach, Enterprise Computing Committee, Office Community Patnership): mempunyai hak dan tugas menjalankan prinsip-prinsip IT, dan mengambil keputusan tingkat tinggi mengenai peran strategis IT dalam bisnis perguruan tinggi (domain pertama framework IT governance Weill dan Ross). Institusional Ownership juga menjalankan hak dan fungsi domain prioritas dan investasi (domain kelima framework Weill dan Ross) yaitu memutuskan berapa banyak dan dimana investasi IT akan dilakukan, termasuk menyetujui proyek-proyek IT dan pembenaran teknik lainnya.

2. Campus Direction, Coordination, Policy (Information Technology Planning Board - Office of Informatioan Technology). Bagian ini berhak dan menjalankan fungsi-fungsi dan prinsip-prinsip, namun lebih fokus kepada program aksi dan rekomendasi penerapan IT governance pada perguruan tinggi seperti yang telah ditetapkan dan diputuskan oleh Institutional Ownership (sejalan dengan domain pertama dan kelima framework IT Governance Weill dan Ross) 
3. Functional Planning Oversight (Faculty Committee of Educatin Technology, Cimputational Research Faculty Advisory Board, Office of Informatioan Technology, Enterprise Computing Committee, Steering Committee). Mempunyai wewenang dan fungsi dalam menetapkan persyaratan bisnis produk IT yang akan dibeli atau aplikasi IT yang akan dikembangkan secara internal (sejalan dengan domain keempat framework IT governance Weill dan Ross).

4. Areas of Emphasis (Student Integration, Research Leadership, Scholary Interaction, Increased Production, Community). Merupakan bentuk spesifik proses bisnis yang ada di perguruan tinggi secara umum. Penetapan area ini sejalan dengan domain pertama (Prinsip-prinsip IT), domain keempat (Aplikasi kebutuhan bisnis), dan domain kelima (Prioritas dan investasi) pada framework IT governance Weill dan Ross.

5. Infrastructure (Common Infrastuktur and Area Spesific). Domain ini mempunyai hak dan fungsi sebagai pusat koordinasi layanan IT bagi lembaga perguruan tinggi. Termasuk didalamnya memberikan dasar bagi kemampuan organisasi IT, dibuat sebelum kebutuhan penggunaan yang tepat diketahui. Area ini sejalan dengan domain ketiga framework IT governance Weill dan Ross (Infrastruktur IT).

6. Technical Planinng Oversight (Common System Group - Campus Computing Council). Berhak dan mempunyai tugas dalam menetapkan pilihan teknik untuk menuntun organisasi perguruan tinggi dalam memenuhi kebutuhan bisnis organisasi. Area ini sejalan dengan domain kedua framework IT governance Weill dan Ross (Arsiterktur IT).

\section{Simpulan}

Penerapan IT governance yang sesuai dengan prinsip, cara kerja, framework dan mekanisme implementas IT governance pada perguruan tinggi diharapkan dapat meningkatkan performance, kemudahan, kecepatan, efisiensi, dan efektifitas kegiatan back office dan fornt office. Bahkan pada batas-batas tertentu, penerapan good IT governance dapat menawarkan dan membuka banyak peluang bagi perguruan tinggi dalam mentransformasi pelayanan, pasar, proses kerja, hubungan belajar-mengajar, meneliti, berbagai kepentingan stakeholder, dan dapat meningkatkan keunggulan kompetitif secara global. Karena itu perguruan tinggi hendanya memiliki IT governance yang sama baiknya dengan corporate governance.

Untuk dapat memiliki good IT governance, perguruan tinggi harus memperhatikan dan menerapkan prinsip dasar dan framework IT governance, menetapkan dan memilih prototype dan mekanisme implementasi IT governance yang 
tepat (sesuai dengan kebutuhan spesifik perguruan tinggi). Sementara itu, agar dapat mencapai tujuan secara efektif, maka I $T$ governance di perguruan tinggi hendaknya mempunyai minimal enam struktur utama, yaitu: (1) Institutional Ownership, (2) Campus Direction, Coordination, Policy - Information Technology Planning Board, dan Office of Informatioan Technology, (3) Functional Planning Oversight, (4) Areas of Emphasis, (5) Infrastructure - Common Infrastuktur and Area Spesific, dan (6) Technical Plannng Oversight - Common System Group, dan Campus Computing Council.

\section{Pustaka:}

1. SearchClO.com, (2005), Executive Guide:IT governance, www.kpmg.ca/enservices/advisory/err/inforiskmgmt.html, 11 J uli (2008).

2. Ross, J eanne, and Weill, Peter. Recipe for Good Governance, ClO Magazine, 15 June(2004), 17, (17).

3. Peter Weill and J eanne Ross, (2004), IT Governance: How Top Performers Manage IT Decision Rights for Superior Results, Harvard Business Press. Excerpt available online at http://hbswk.hbs. edu/archive/4241.html

4. Henderi dan Sunarya Abas, (2008), Peranan IT Governance Dalam Meningkatkan Kinerja Organisasi: Permasalahan, Rencana Pengembangan dan Strategi Penerapan. CCIT J ournal 2(1), 1-12

5. www.consultfuture.com/download/COBIT/Overview/and/ITIL/Mapping, 28 Lanuari 2010

6,7,8. Peter Weill and J eanne Ross, 2004, IT Governance on One Page, Center for Information Systems Research, Sloan School of Management, Massachusetts Institute of Technology, http://web.mit.edu/cisr/working\%20papers/ cisrwp349.pdf

9. $\quad$ http://web. mit.edu/ist/org/IST-staff-orgchart.pdf, http://web.mit.edu/ist/org

10,11. http://web.mit.edu/ist/about

12. http://www.universitycio.harvard.edu/cio_organization

13. http://www.universitycio.harvard.edu/central_administration_it

14,15. http://www.it.ubc.ca/about.html

16. http://www.e-strategy.ubc.ca/initiatives.html 